\title{
The Red Rock ice cliff revisited - six decades of frontal, mass and area changes in the Nunatarssuaq area, Northwest Greenland
}

\section{Article \\ Cite this article: Abermann J, Steiner JF, Prinz $R$, Wecht M, Lisager P (2020). The Red Rock ice cliff revisited - six decades of frontal, mass and area changes in the Nunatarssuaq area, Northwest Greenland. Journal of Glaciology 66 (258), 567-576. https://doi.org/10.1017/ jog.2020.28}

Received: 18 November 2019

Revised: 26 March 2020

Accepted: 27 March 2020

First published online: 23 April 2020

\section{Key words:}

Arctic glaciology; glacier fluctuations; glacier mass balance

\section{Author for correspondence:}

Jakob Abermann, E-mail: jakob.abermann@ uni-graz.at (c) The Author(s), 2020. Published by Cambridge University Press. This is an Open Access article, distributed under the terms of the Creative Commons Attribution licence (http://creativecommons.org/licenses/by/4.0/), which permits unrestricted re-use, distribution, and reproduction in any medium, provided the original work is properly cited.

\author{
Jakob Abermann ${ }^{1,2}$ (D), Jakob F. Steiner ${ }^{3}$, Rainer Prinz ${ }^{4}$ (D), Matthias Wecht ${ }^{1}$ \\ and Peter Lisager ${ }^{2}$
}

\footnotetext{
${ }^{1}$ University of Graz, Heinrichstraße 36, 8010 Graz, Austria; ${ }^{2}$ Asiaq, Greenland Survey, PB 1003, 3900 Nuuk, Greenland; ${ }^{3}$ Department of Physical Geography, Utrecht University, PO Box 80115, Utrecht, The Netherlands and ${ }^{4}$ Department of Atmospheric and Cryospheric Sciences, University of Innsbruck, Innrain 52, 6020 Innsbruck, Austria
}

\begin{abstract}
We present changes of the ice margin in Northwest Greenland at the Eastern part of the Nunatarssuaq Ice Cap (NIC) over six decades. The ice margin in this area terminates as a near-vertical ice cliff of between 9 and $33 \mathrm{~m}$ thickness. During the years 1954-1957 and in 1965 multi-disciplinary studies were performed. We digitise and orthorectify material, that is often difficult to access, in order to use the historical data as an absolute starting point of our change assessment. We compare the cliff morphology of the mid-1950s and the mid-1960s with various time-steps between 1985 and 2017. The studied ice margin remained remarkably constant with very subtle changes of changing sign: rather slow advance rates are reported from the 1950s and 1960s that accelerated until 1985 and were followed by a general retreat until 2012 and a subsequent advance until 2017. Thickness changes are negative throughout the entire time-period, however, different rates of thinning are shown and there is a positive relationship with air temperature anomalies. Compared to similar elevations on the adjacent Greenland ice sheet, we find significantly weaker thinning rates at the NIC.
\end{abstract}

\section{Introduction}

The land-terminating part of the Greenland ice sheet (GrIS) is by far larger than the marineterminating part - yet has so far received much less attention. Studies that deal with Greenland's land-terminating glaciers have mainly focused on the southern and central West coast (Weidick, 1968; Sole and others, 2008; Tedstone and others, 2015; Carrivick and others, 2018; Lesnek and Briner, 2018; Koziol and Arnold, 2018; Davison and others, 2019), while fewer studies exist for North Greenland (Goldthwait, 1971; Osterberg and others, 2015; Farnsworth and others, 2018). Additionally, most of the glaciers and ice caps (GIC) surrounding the GrIS are land-terminating. The GIC amount to $\sim 5 \%$ of the total ice covered area of Greenland (Rastner and others, 2012; Citterio and Ahlstrøm, 2013), were an important contributor to sea level rise in the past (Jacob and others, 2012; Bolch and others, 2013; Box and others, 2018; Zemp and others, 2019) and are expected to continue to be so in future decades (Machguth and others, 2013; Huss and Hock, 2015; Meredith and others, 2019).

The ice-sheet margins in both Greenland and Antarctica have experienced widespread thinning in recent decades (Pritchard and others, 2009; Howat and Eddy, 2011; Kjeldsen and others, 2015) and generally, marine-terminating tongues thin at higher rates than landterminating ones (Sole and others, 2008; Felikson and others, 2017). Some field studies, however, have shown stability or a temporary advance of land-terminating GIC in both Antarctica (Fitzsimons and Colhoun, 1995; Fountain and others, 2004a; Swanger and others, 2017) and Greenland (Davies and Krinsley, 1962; Goldthwait, 1971; Dawes and van As, 2010; Farnsworth and others, 2018). A comprehensive dataset of length change observations in Greenland (Weidick, 1968; Leclercq and others, 2012) allows for a centennial perspective on glacier fluctuations: generally, retreat dominated since the end of the Little Ice Age with the highest decadal retreat rates in the 1930s. The database focusses on Southwest and West Greenland. For North Greenland, Davies and Krinsley (1962) found a maximum glacier extent for several glaciers in Northwest Greenland between 1920 and 1930; Goldthwait (1961) found organic material at the Red Rock (RR) ice cliff $\sim 30 \mathrm{~m}$ back of the cliff and $41 \mathrm{~m}$ under ice cover at that time, which they dated to be $\sim 200$ years old. This can be taken as evidence of net ice margin advance on a centennial scale; however, it does not reveal information on possible fluctuations or changing advance rates. To our knowledge, there is no direct evidence of high-resolution centennial glacier changes in Northwest Greenland.

The general hypothesis that recent warming could have increased the viscosity of ice and therefore resulted in an advance, has been put forward (Goldthwait, 1971; Fountain and others, 2004a) and for Greenland an increase in accumulation on ice caps has equally been proposed (Davies and Krinsley, 1962; Dawes and van As, 2010), although observations are generally scarce for both local climate and ice dynamics. Larger scale observations suggest a 
dynamic slowdown of the land-terminating sector with an increase in meltwater production due to hydrodynamic coupling (Tedstone and others, 2015).

On the larger spatial scale, Davies and Krinsley (1962) found more of the GIC in North Greenland to be stationary rather than retreating in contrast to a retreating GrIS. The observation of an ice margin stationarity or advance from geodetic measurements is supported with exposure studies carried out decades later, finding evidence for ice margin advances during the late Holocene (Farnsworth and others, 2018). On a longer time-scale, the process of advancing glaciers is relevant for studies as the Greenland ice margin underwent a series of advance and retreat cycles during the Pleistocene (Larsen and others, 2018; Knutz and others, 2019). Revisiting a study area in Northwest Greenland where an advance was reported during the 1950s and 1960s, we provide a detailed history of cliff morphology changes as a basis for further studies investigating the drivers for this behaviour.

\section{The historical context}

During the expansion of Thule Air Base (TAB) in Northwest Greenland and the operation of Camp Century (Colgan and others, 2016), a number of studies focused on the landterminating ice margin in the vicinity of the air base (Hooke, 1970 ) and in a region $\sim 60 \mathrm{~km}$ to the northeast where a local ice cap with the unofficial (Bjørk and others, 2015) but widely used name Nunatarssuaq Ice Cap (NIC) and the GrIS meet (Goldthwait, 1956, 1961, 1971) (Fig. 1). The area directly adjacent to GrIS was named Red Rock (RR) after its apparent colour and the stretch with a near-vertical cliff, the RR ice cliff. Their main motivation was of military and engineering nature, the access to the ice sheet with heavy loads being a central issue.

During several consequent field expeditions in 1955, 1956 and 1965, each lasting for between a few weeks and several months, a number of scientists around Richard P. Goldthwait investigated the terrestrial ice margin with geodetic, glaciological and meteorological methods resulting in a number of reports and articles that we collected for this study from various sources (Goldthwait, 1956, 1960, 1961, 1971; Hilty, 1956; Jury, 1957; Landauer, 1958; White, 1958; Nobles, 1960, 1964). Detailed maps of the vertical ice margin, observations of its development over a period of a decade and stake and ice temperature measurements at a number of locations are documented in these publications. The stretch of the ice cliff they describe was composed of a clean ice part in the upper 5-25 $\mathrm{m}$ of the cliff on top of a part of debris-containing amber ice in the lower $5 \mathrm{~m}$ of the cliff (Goldthwait, 1960). Their main findings are that (i) during the decade 1955-1965, the land-terminating ice cliff was advancing at a rate of $0.2 \mathrm{~m}$ $\mathrm{a}^{-1}$ and concurrently thinning at $0.6 \mathrm{~m} \mathrm{a}^{-1}$ (Goldthwait, 1971), (ii) the ice was cold at a temperature of between -12 and $-16^{\circ}$ $\mathrm{C}$ at $6 \mathrm{~m}$ depth and dry based (Hilty, 1956) and (iii) they suggest an annual cycle of cliff morphology changes: an oversteepening during winter due to the absence of surface or frontal ablation is followed by early summer ice warming that triggers dry calving, melt and sublimation and yields a vertical cliff by the end of the summer (Goldthwait, 1960). To our knowledge, research activities at this field site ceased in 1965, a time in history where US activities in this part of Greenland reduced following a change in political interest (Nielsen and Nielsen, 2016; Colgan and others, 2016).

An intriguing property of the ice around the $R R$ is a darker band of ice (Fig. 1b and Figs 2e-h). This has been mentioned already in the early reports (Goldthwait, 1956), referred to as 'amber ice' and was attributed to shear entrainment and multiple folding of the ice subsequently (cf. Evans, 1989). The main interest in the Goldthwait literature however, seems energy balance related and they find indeed higher melt rates at the darker amber bands. Chinn (1989) investigated similar features in the Antarctic Dry Valleys and attribute those to debris entrainment and hence postulate a local origin. A pioneering work on various locations around the Greenland ice margin summarised by Reeh and others $(1991,2002)$ confirms a pre-Holocene origin of the amber band and successfully relates it to deep ice core isotope records of the bottom of the ice sheet. Their conclusion is hence, that it is advected ice originating in palaeo-accumulation zones of the GrIS.

\section{Data and methods}

For change detection at the ice margins we use historical data and various remote-sensing products (see Table 1). Only highresolution products are relevant for the analysis of cliff changes since changes are small and otherwise masked by noise. This makes image resolution of $10 \mathrm{~m}$ or lower not usable for this study. We base our change detection on five points in time (1955, 1965, 1985, 2012 and 2017, see Table 1 for details on source, acquisition date, accuracy and resolution).

In order to quantify changes in the period 1955-1965, the team around R. Goldthwait established a $420 \mathrm{~m}$ long survey line from which 15 profiles, each $\sim 30 \mathrm{~m}$ apart were surveyed across the cliff face. Most of the results they present relate to changes referring to this survey line and for cliff front changes they rely on profiles 5-15 (Goldthwait, 1971, Fig. 5). Figure 2 in Goldthwait (1971) ('F2GW1971' henceforth in order to avoid confusion with figures presented in this study) shows the survey line's position relative to the cliff in 1965. While this allows for locating the position of the survey line approximately, we are not able to use F2GW1971 alone in order to determine changes in cliff position for later years due to the ice margin's changing nature. Unfortunately, both absolute coordinates and stable features, which could be identified in past and recent maps, are missing. Hence, to quantify changes between 1955 and 2017, we need to georeference the past maps using their meta-information and a regression analysis comparing ice-free areas between the time periods. The north arrow (pointing towards true north) in the upper right corner of F2GW1971 however, lets us determine the west/east orientation of the map $\left(5.6^{\circ}\right.$ turn anticlockwise). In Appendix B, Table B1, Goldthwait (1971) also provides elevation values of the survey line (base stakes 1-15 relative to stake 1) which are in line with the qualitative description of the survey line of Jury (1957). We derive potential survey lines on the Pleiades 2017 DEM to reconstruct the 1956 survey line. Therefore, we created an artificial grid of points each $1 \mathrm{~m}$ apart that has a west/east orientation fitting the information we have from F2GW1971 with a length of $900 \mathrm{~m}$ and a width of $200 \mathrm{~m}$. We chose the extent in a way that we would cover all plausible positions of survey lines with respect to the definite natural limits of the RR Lake; the red box in Figure 3a corresponds to the extent of plausible solutions. We then run through the set of potential survey lines, each base stake $30 \mathrm{~m}$ apart and derive elevations relative to the position of base stake 1 from the Pléiades 2017 DEM. For each potential survey line, we determine the coefficient of determination $\left(R^{2}\right)$ and the RMSE between the elevation of the survey line presented in F2GW1971 and the potential survey line derived from the 2017 Pléiades DEM. We emphasise that all potential survey lines that were considered are on ice-free terrain during the time period in question. Figure $3 \mathrm{a}$, b show results for RMSE and $R^{2}$, respectively, and Figure 4 indicates the relative elevation of the two best-fitting reconstructed profiles together with the reference line from F2GW1971 with base stake 1 as datum. Two results show similar 

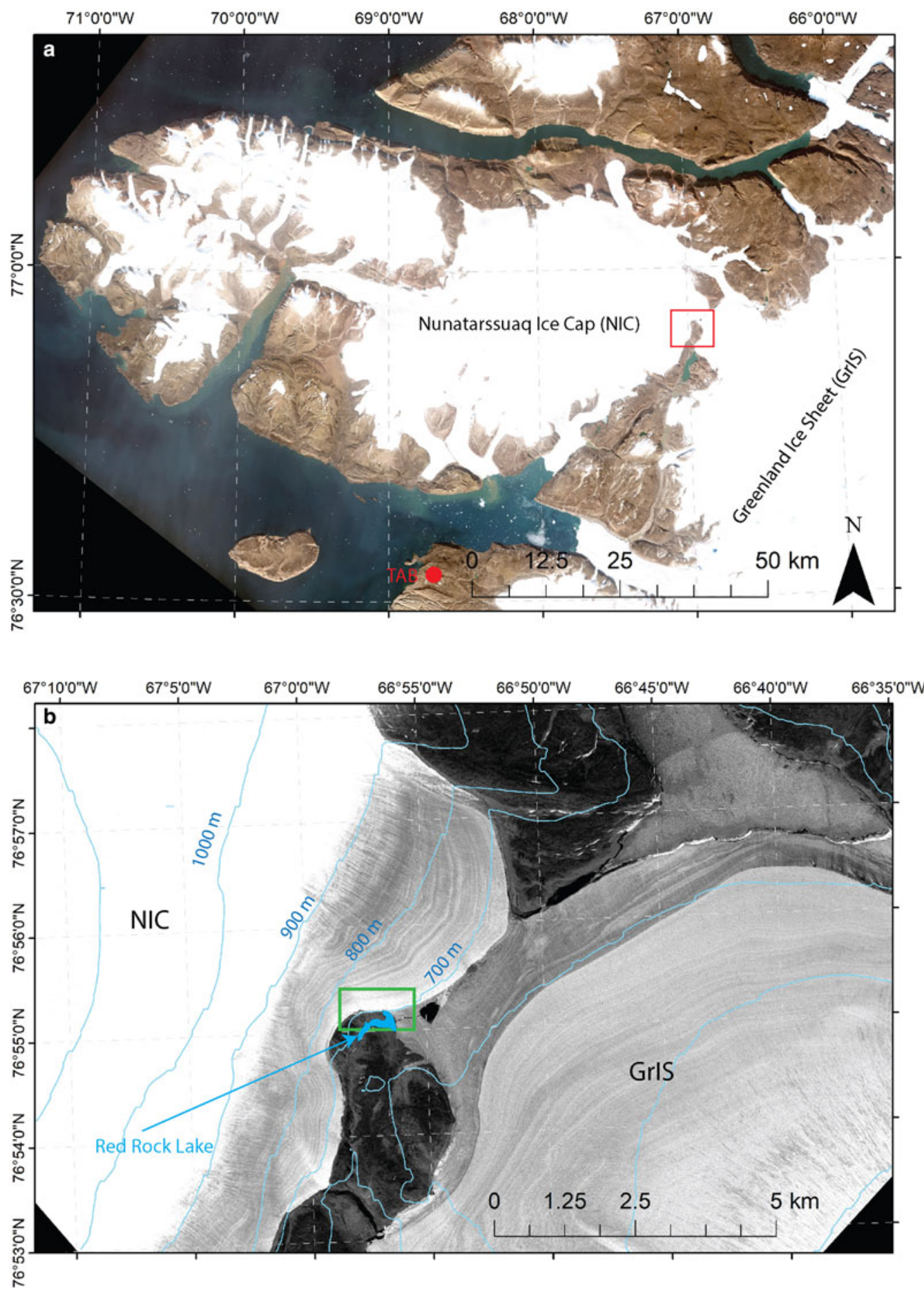

Fig. 1. (a) The study area in Northwest Greenland with the NIC, the GrIS and TAB marked. The background image is a Landsat8 scene from 22 August 2017 (LC80310052017234LGN00). (b) Close-up indicated by the red square in (a). The green square in (b) shows the area of the RR ice cliff, and RR Lake is marked and shown in blue.

and both near-perfect fit with slightly higher $R^{2}$ values for case A. Apart from case A showing a better fit, the derived advance/retreat history is also more plausible when georeferencing F2GW1971 aligning with case $\mathrm{A}$ as case B would require unrealistically large advance rates ( $4 \mathrm{~m} \mathrm{a}^{-1}$ over two decades) followed by strong retreat rates, which does not fit to observed climate fluctuations nor thickness changes (see 'Results' section). Hence, we orthorectify F2GW1971 to case A of the potential survey line (Fig. 3c). Figure $3 c$ shows the position of the survey line as we determined it using F2GW1971 (half-transparent) and the 15 perpendicular profiles. Since F2GW1971 displays the position of the ice margin in 1965, we take this as the reference and determine the absolute position of the margin in 1956 by applying the relative cliff position changes between 1956 and 1965 as described by Goldthwait (1971). In this report, only changes east of profile 5 are described, likely due to the fact that the cliff morphology to the west is not that clearly developed, and hence the advance or retreat rate could not be clearly determined. For the same reason, we refer to the average of profiles 6-15 when we determine average rates of change. Furthermore we are able to reconstruct a DEM by digitising the 1965 contours and applying the thickness changes from F2GW1971, we can 


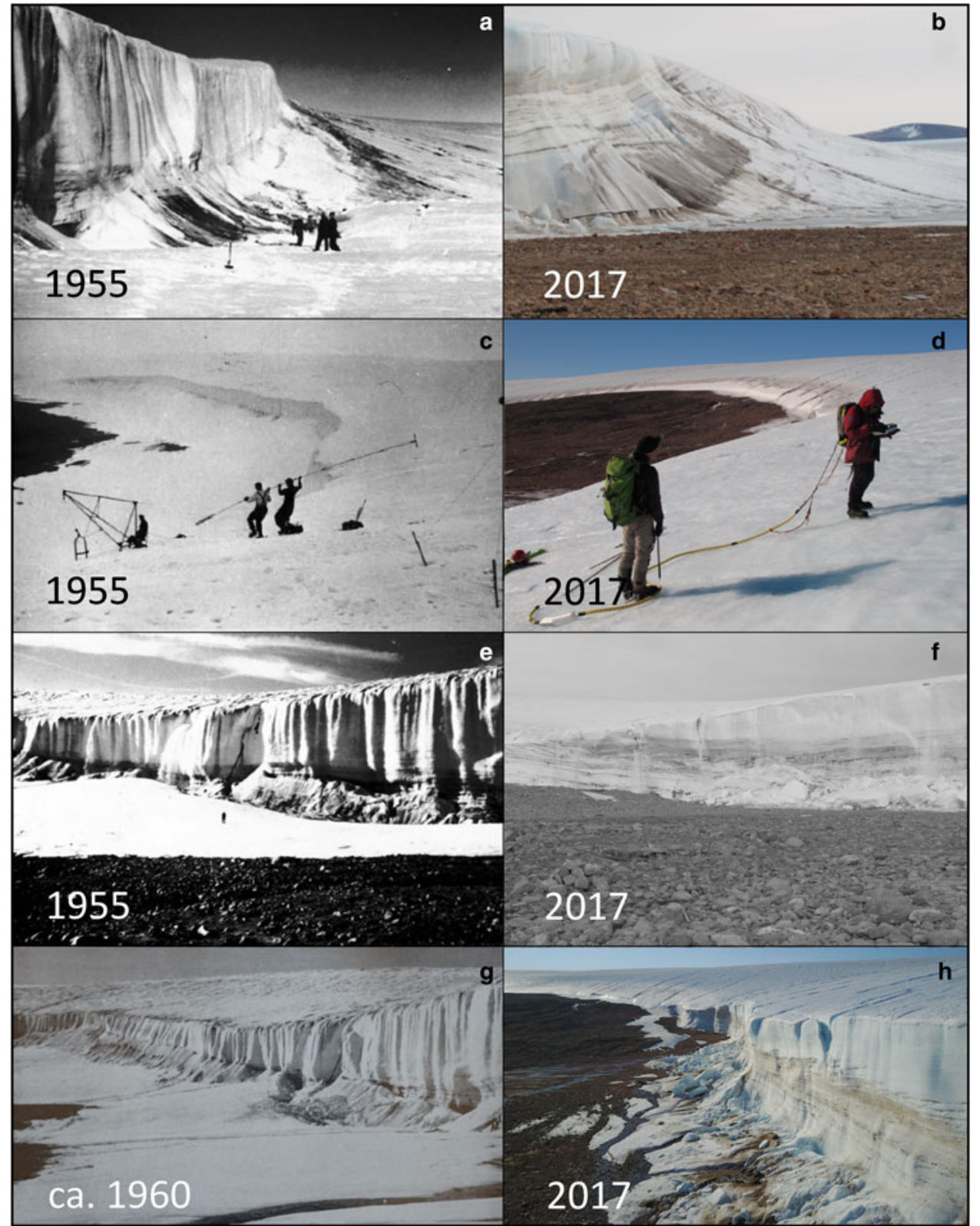

Fig. 2. Photographs from the campaigns in the 1950s and 1960s: (a, c, e) Hilty (1956); (g) Fristrup (1963) and from the approximate locations in 2017 (b, d, f, h). Note the fact that the amber part covers a larger fraction of the cliff face in 2017 than in the 1950s and 1960s.

then reconstruct the 1956 DEM. By georeferencing this figure we were therefore able to directly compare the results from the Goldthwait campaigns with more recent remote-sensing products.

The 1985 DEM (Korsgaard and others, 2016) shows a high degree of interpolation just around the cliff edge. This is the reason why we do not calculate or display thickness changes at the cliff edge there. Fortunately, the original $2 \mathrm{~m}$ orthoimages are also provided by Korsgaard and others (2016) and with confidence we use the relevant one ('g150_1985_utm19.jp2') in order to determine the position of the 1985 cliff edge after georeferencing it to the Pléiades orthoimage.

Table 1. Overview of the data used in this study including the acquisition date, image resolution, the DEMs' resolution and wherever performed, the co-registration results

\begin{tabular}{lccccc}
\hline Source & Year & $\begin{array}{c}\text { Resolution image } \\
\mathrm{m}\end{array}$ & $\begin{array}{c}\text { Resolution DEM } \\
\mathrm{m}\end{array}$ & $\begin{array}{c}\text { Co-registration shift } x \\
\mathrm{~m}\end{array}$ & $\begin{array}{c}\text { Co-registration shift } y \\
\mathrm{~m}\end{array}$ \\
\hline DEM 1956 & 1956 & & 5.0 & $\begin{array}{c}\text { Co-registration shift } z \\
\mathrm{~m}\end{array}$ \\
DEM 1965 & 1965 & & 5.0 & -6.9 & 2.3 \\
AeroDEM & 1985 & 2.0 & 25.0 & -2.3 & 3.0 \\
ArcticDEM & 2012 & 0.4 & 1.0 & 3.5 \\
Pléiades & 2017 & 0.5 & 0.0 & \\
UAV & 2017 & 0.02 & 10.0 & \\
GPR & 2017 & - & & & \\
ESA surface velocity & 2018 & 500 & &
\end{tabular}




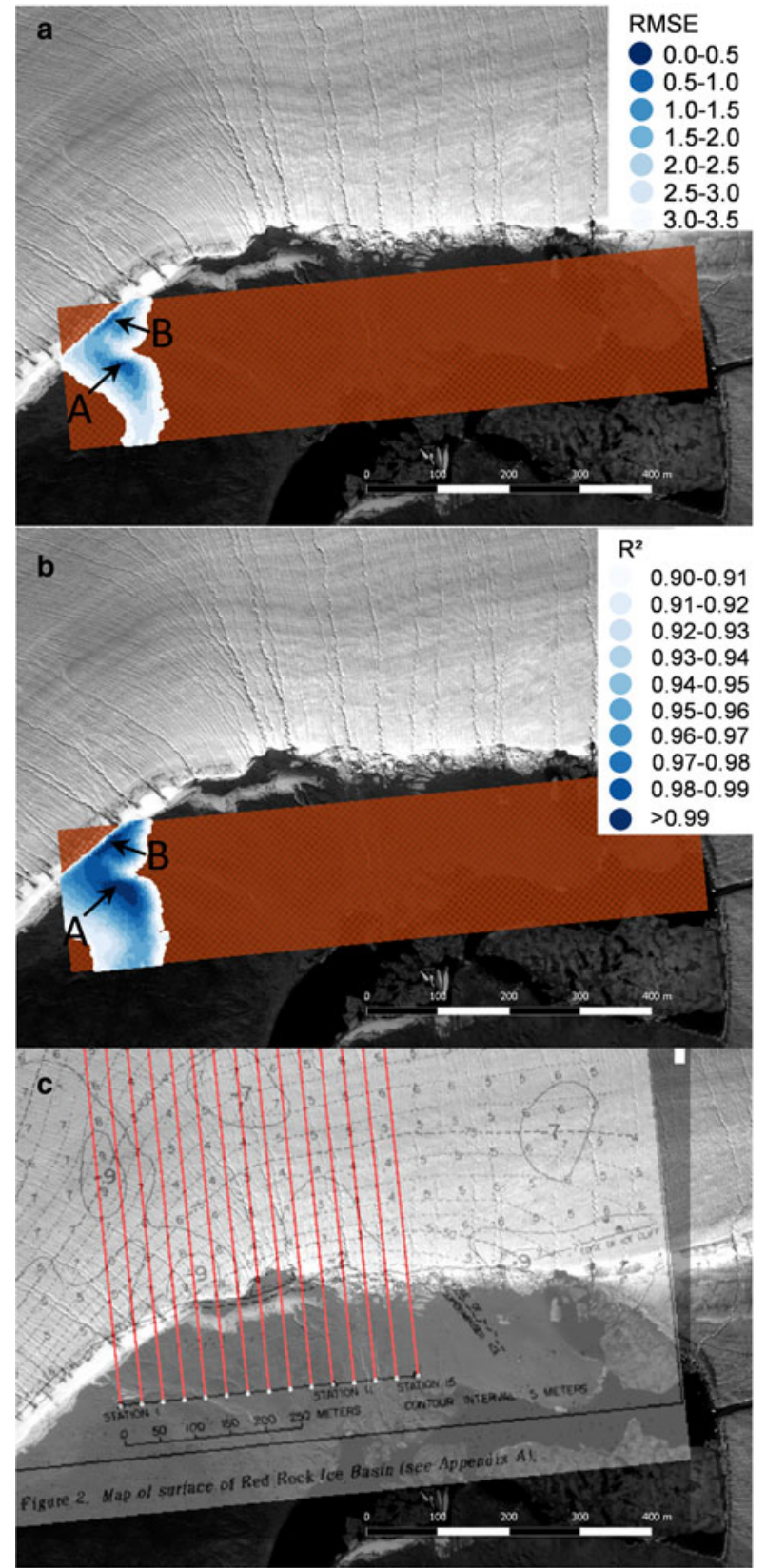

Fig. 3. (a) RMSE, (b) $R^{2}$ and (c) the orthorectified Figure 2 from Goldthwait (1971) overlaid over the Pléiades orthoimage with the determined survey line (white dots) and the perpendicular profiles (red). The two best-fitting reconstructions of the location of base stake 1 of the survey line from 1956 are denoted by A and B.

For deriving front position and thickness change from the remote-sensing sources after 1985, a 2-D co-registration procedure following Nuth and Kääb (2011) was performed and the 1985 and the 2012 DEM aligned to the Pléiades DEM of 2017. The Pléiades DEM is of high quality and derived using the AMES stereo pipeline (Shean and others, 2016). The value of this high-resolution imagery has earlier been shown in detail in glaciological studies (Berthier and others, 2014; Prinz and others, 2018). The horizontal shift introduced by the co-registration of the 1985 and 2012 DEMs, respectively, is shown in Table 1 and amounts to $<7 \mathrm{~m}$ in one direction. In order to derive thickness changes, we apply a vertical correction to both the AeroDEM and the ArcticDEM. This was done by calculating the mean difference with the Pléiades DEM at bare ground south of the cliff front for each profile of the survey line. This difference was used to bias-correct the 1985 and 2012 DEMs. Deviations

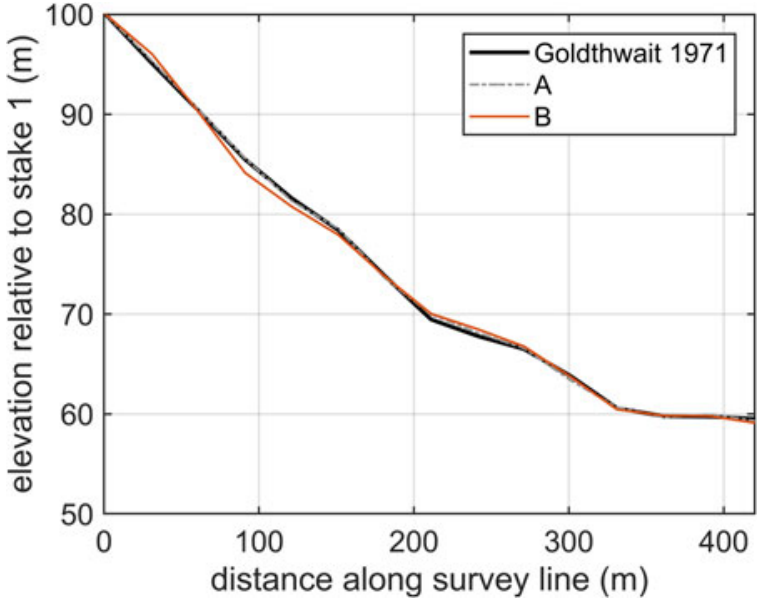

Fig. 4. The relative elevation of the survey line as given in Table B1 in Goldthwait (1971) with 100 referring to the elevation of stake 1 as the datum and the two bestfitting options $\mathrm{A}$ and $\mathrm{B}$ (both $R^{2}>0.99$ and RMSE $<0.5 \mathrm{~m}$ ) derived from the Pléiades DEM.

remained below $3.5 \mathrm{~m}$ (Table 1). For the DEM-derived mean thickness changes at the cliff top, we used the co-registered and bias-corrected top of the ice cliffs at locations not impacted by the advance of the cliff front (on average at $735 \mathrm{~m}$ a.s.l.) and computed the average thickness change over profiles 6-15 across the survey line. In order to discuss spatial gradients between the NIC and the GrIS we apply the same co-registration corrections to the entire DEM.

Cliff thickness as well as the thickness of the amber ice part for 1956 were derived by digitising Fig. 26 in Goldthwait (1960). We compare this with the thickness of the cliff from the Pléiades DEM and determine the thickness of the amber part in 2017 from the UAV-derived orthophoto which was acquired for the cliff front.

The UAV-based image data were processed using the commercial software Agisoft Photoscan Professional (v. 1.2.3 2735) based on the structure-from-motion principles. General steps of the processing were: (1) computation of the sparse point cloud in order to find the relative camera position and orientation for each photo, (2) location of markers in the individual images to set up the coordinate system and refine alignment optimisation, (3) bundle adjustment and camera calibration, (4) creation of a dense point cloud and computation of the DEM by rasterisation of the dense point cloud which eventually led to a (5) georeferenced orthophoto of the front of the cliff for which the height of the amber part relative to the cliff bottom could be determined. Since we take both cliff position and thickness changes relative to 2017 from the Pléiades DEM, we use the UAV-based DEM merely for quantification of the thickness of the amber part of the cliff, which is why the co-registration with the other remote-sensing products is not necessary.

During the 2017 field campaign, GPR data were acquired in situ with a Malå GPR and a $100 \mathrm{MHz}$ rough terrain antenna acquiring grid lines of $\sim 30 \mathrm{~km}$ in total. We use Reflex software in order to derive the ice thickness across the profiles and interpolate the results to a $10 \mathrm{~m}$ grid. We estimate an overall accuracy of $10 \mathrm{~m}$, including a positional error.

Long-term homogenised meteorological data exist from TAB since 1947. An access to air temperature data was obtained from Cappelen and others (2018). For precipitation, we used biascorrected and homogenised data from Wong and others (2015). A bias-correction was applied for the missing recent years (Bales and others, 2009) for which the raw data were provided by J. Cappelen (personal communication). 
Fig. 5. Profiles 5-15 of the RR ice cliff front as shown in Figure 3c. The cliff position of 1985 is taken from the orthoimage, hence the elevation is set to $30 \mathrm{~m}$ arbitrarily and should only indicate the location, not the height. For profiles 5-9 in the upper part of the profile, the quality flag of the DEM is high enough in order to interpret cliff morphology. Five time-steps between 1955 and 2017 of the surface are shown. In addition, the measured bedrock (BR GPR) as well as the interpolated stretches (BR interp) and the elevation of the lake level are shown.

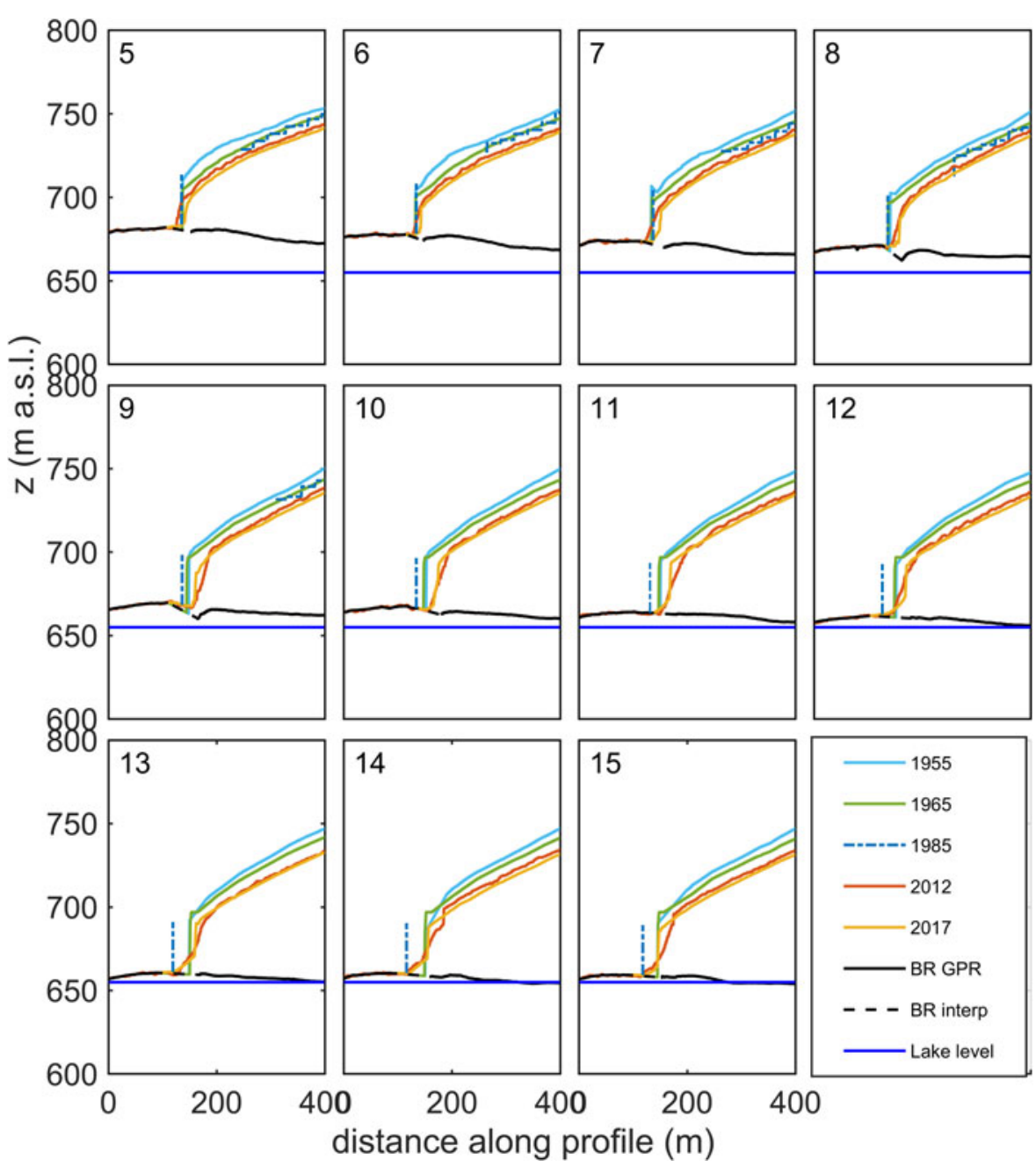

\section{Results}

Figure 5 shows the surface morphology changes of profiles 5-15 from 1955 to 2017. It is apparent that cliff position changes along the profiles are stronger at the eastern side (higher profile numbers) than at the western side (lower profile numbers) of the cliff front. While profiles $5-8$ for instance show a very stable cliff position during the six decades studied, stronger changes occur from profile 10 upwards. Results show that the minor advance between 1955 and 1965 already described by Goldthwait (1971) continued and increased in magnitude until 1985, whereafter all profiles (except for profile 5) show a retreat until 2012. Between 2012 and 2017, a minor advance at the eastern part of the survey line occurred. Profiles with flatter bedrock, with an overdeepening behind the cliff front and with larger ice thicknesses closer to the lake level reveal both higher advance and retreat rates. In terms of thickness changes distinct and continuous thinning has taken place between 1955 and 1965. Profiles 5-9 (Fig. 5) show only a very slight additional thinning until 1985. Thereafter through 2012 and until 2017 the thinning continued at all profile lines. Overall, at profiles 5-13 a net retreat of the cliff position occurred between 1955 and 2017 while profiles 14 and 15 remained at the same position as they were six decades ago.

Figure 6 gives a frontal representation of the cliff height comparing 1956 and 2017 on the basis of Goldthwait (1960, 1971), the Pléiades DEM for cliff height and the UAV orthoimage for the height of amber ice in 2017, respectively. Amber ice refers to the distinct darker band of debris near the bottom of the cliff. While the comparison of the cliff height for both points in time shows the general thinning, it is striking that both absolute and

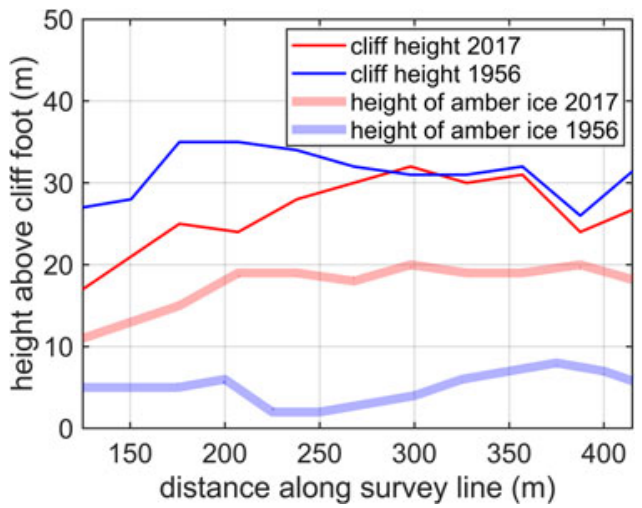

Fig. 6. Ice cliff height above bottom and the height of amber ice for 1956 (Goldthwait, 1960) and 2017 (Pléiades DEM; UAV survey).

relative thickness of the amber part have increased significantly. While in 1956 the amber part was on the order of $5 \mathrm{~m}$ and in all profiles below $10 \mathrm{~m}$, we notice a thickening to between 15 and $20 \mathrm{~m}$ in 2017 . This is independently confirmed by photographic evidence (Fig. 2).

In order to facilitate comparison, in the following we average over profiles 5-15 and derive the rates of change for both thickness and front position changes (Table 2, Fig. 7a). While the periods 1955-1985 and 2012-2017 show a general average advance, the period 1985-2012 shows a significant retreat. The largest average advance rates occurred in the most recent period 2012-2017 
Table 2. Period average of summer air temperature anomaly $A T_{A N O}\left({ }^{\circ} \mathrm{C}\right)$ for $T A B$, precipitation anomaly $P_{\text {ANO }}(\mathrm{mm})$ for TAB, ice thickness changes $\Delta z(\mathrm{~m})$, rate of ice thickness change $\Delta z / \Delta t\left(\mathrm{~m} \mathrm{a}^{-1}\right)$, front position change $\Delta L(\mathrm{~m})$ and rate of front position change $\Delta L / \Delta t$ for the respective time periods

\begin{tabular}{lcrrrrrr}
\hline Start year & End year & $\begin{array}{c}A T_{\text {ANO, JJA }}{ }^{\circ} \mathrm{C} \\
\text { Enm }\end{array}$ & $\begin{array}{c}P_{\text {ANO }} \\
\mathrm{mm}\end{array}$ & $\begin{array}{c}\Delta z \\
\mathrm{~m}\end{array}$ & $\begin{array}{r}\Delta z / \Delta t \\
\mathrm{~m} \mathrm{a}\end{array}$ & $\begin{array}{r}\Delta L \\
\mathrm{M}\end{array}$ & $\begin{array}{r}\Delta L / \Delta t \\
\mathrm{~m} \mathrm{a}^{-1}\end{array}$ \\
\hline 1955 & 1955 & 0.1 & 6.7 & -0.6 & -0.6 & & \\
1956 & 1956 & -0.4 & -69.5 & -1.5 & -1.5 & 0.5 & 0.5 \\
1965 & 1965 & -0.1 & -1.2 & -5.3 & -0.6 & 1.6 & 0.2 \\
1985 & 1985 & -0.6 & -22.2 & -2.4 & -0.1 & 14.4 & 0.7 \\
2012 & 2012 & 0.1 & -3.2 & -4.5 & -0.2 & -45.9 & -1.7 \\
\hline
\end{tabular}
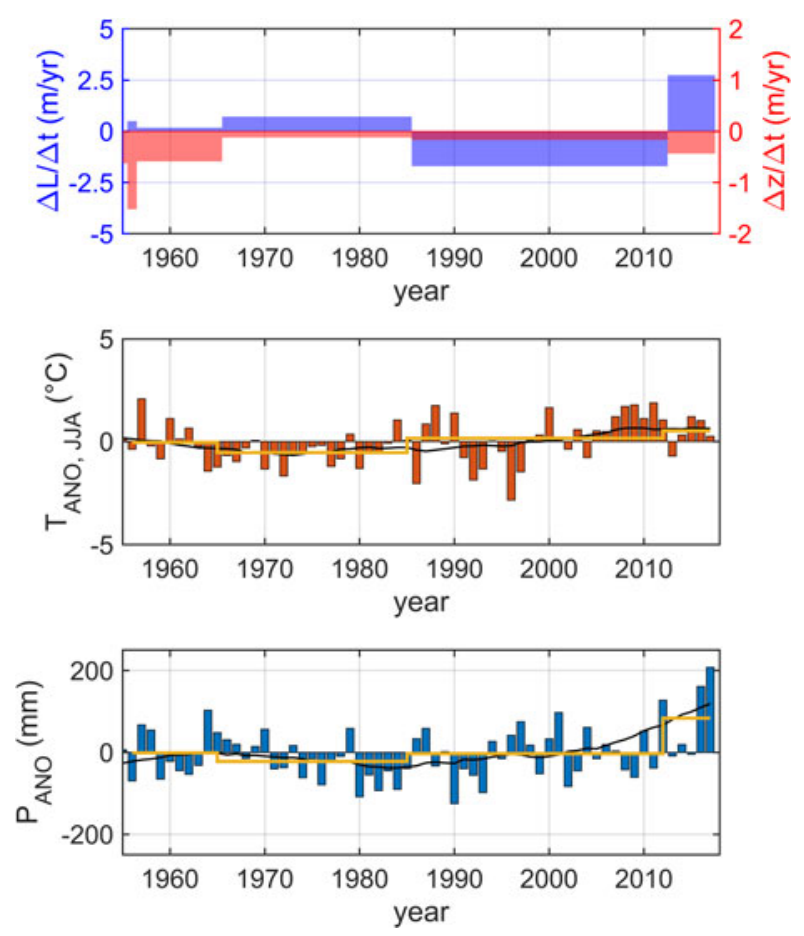

Fig. 7. (a) Rates of cliff position and rates of thickness change for the respective time periods; (b) summer air temperature anomaly $\left(T_{\mathrm{ANO}}, J_{\mathrm{JA}}\right)$ and $(\mathrm{c})$ annual precipitation anomaly $\left(P_{\mathrm{ANO}}\right)$ for TAB, respectively. Both (b) and (c) refer to 1981-2010 (average $T_{\text {JJA }}$ for $1981-2010$ is $4.3^{\circ} \mathrm{C}$; average $P$ is $181 \mathrm{~mm}$ ). The black line in (b) and (c) gives a 5 year moving average and the yellow line the averages of the anomalies for the same periods for which the geometric changes are known.

with more than $2.5 \mathrm{~m} \mathrm{a}^{-1}$ on average, which is mainly caused by the easternmost part of the cliff. Thinning occurred throughout the entire time period although at different rates. Strong thinning rates occurred in the first decade of the study period and ever since the thinning rates increased on average within the period 2012-2017 showing a thickness change of $-0.4 \mathrm{~m} \mathrm{a}^{-1}$.

DEM differencing allows putting the results into a larger broader spatial perspective. Figure 8 shows the rate of surface elevation change for the two periods 1985-2012 and 2012-2017, where DEMs for a larger domain are available. It is evident that close to the cliff edge, there is a blue rim, i.e. an apparent thickening between 1985 and 2012. As discussed above, this coincides with an unreliable portion of the 1985 DEMs (Korsgaard and others, 2016) and given the advance rates until 1985 that we derived from the orthoimages this does not appear realistic. Between 2012 and 2017, a minor stretch of the cliff advanced and the remainder of the edge is stagnant or retreated. During our field campaign we encountered organic material being pushed up along the cliff front, particularly in its central/eastern portion which allows for an independent indication of a stationary or slightly advancing cliff front. What is also notable in Figure 8 is that the lower parts of the GrIS thin at a stronger rate than NIC. This coincides with a spatial gradient in horizontal displacement, as recent Sentinel-derived velocity maps (Nagler and others, 2015) depict slightly higher flow velocities at NIC compared to GrIS, indicating dynamic downwasting at the GrIS.

\section{Discussion}

Both the cliff front position and thickness underwent some variations over the last six decades. It thus seems prudent to relate the observed changes to atmospheric drivers. TAB's long-term climate monitoring is comparably close to the study site, where similar anomalies may be expected, despite the different elevation of TAB (close to sea level) and RR (in $\sim 700 \mathrm{~m}$ a.s.l.). While the elevation difference likely mainly manifests in a temperature offset as temperature anomalies are generally spatially correlated over large distances, we expect a systematically reduced precipitation at RR due to a larger distance to the ocean as a humidity source which is only partly balanced by a vertical precipitation gradient (Wong and others, 2015). Table 2 and Figure $7 \mathrm{~b}$ and $\mathrm{c}$ show that before 2012 the overall anomalies in summer air temperatures $\left(T_{\mathrm{ANO}, \text { JJA }}\right)$ and annual precipitation $P_{\mathrm{ANO}}$ relate to the anomalies in geometry changes. The period 1965-1985 for instance shows that both an advance and the lowest thinning rates coincide with the period of most negative values of $T_{\mathrm{JJA}}$, ANO and $P_{\mathrm{ANO}}$. Dry and cool periods hence favour advance by reducing ablation. In very recent years the strongest positive $T_{\mathrm{JJA}}$, ANO however coincide both with a positive $P_{\text {ANO }}$ and a strong thinning with a concurrent advance. While the strong thinning can be explained by the positive air temperature anomalies favouring ice melt, the advance seems to be of the reversed response compared to earlier periods. Fountain and others (2004b) discuss the potential of increased deformation through ice softening as a result of longterm warming. In light of this, it would be of very high relevance to repeat the ice temperature measurements that exist and are particularly well documented (Hilty, 1956), especially since after this study, we are able to rather accurately reproduce the original measurement sites. It would be of great interest to use this unique high-temporally resolved dataset in order to challenge ice flow on a very high spatial resolution.

The temporal resolution and direct historically derived glacial history of our study is unique, however, we are only able to resolve glacier changes on a multi-year scale. Given potentially very long dynamic response times we may observe a geometry changes (i) occurring on different time scales and/or (ii) driven by climate fluctuations from before our period of available data. Again, ice flow modelling could help resolving this further and this study is a precondition towards that.

The relative and absolute increase of debris loaded amber ice at the cliff front is an intriguing component of our observations. We speculate that the origin of the amber ice near the foot of the cliff is likely to be connected to a dark band exposed at the GrIS at $\sim 700 \mathrm{~m}$ and below (see also Fig. 1b). The fact that the transition from amber to bright ice is higher up in the exposed cliff front in 2017 compared to historical data can potentially point to the inclination of the amber part upstream and entrainment of debris from below, which is suggested by previous studies in similar environments (Chinn, 1989; Fitzsimons and others, 2008). More detailed GPR surveys, modelling studies or ice coring may be able to answer the origin and fate of this debris band and potentially bear potential for relevant palaeo-climatic inverse modelling approaches. A different connection could be a general debris-laden ice layer near the bedrock-ice interface that has been observed among others in the Camp Century Ice Core, which is $\sim 150 \mathrm{~km}$ further inland (Herron and Langway, 1979) and has 


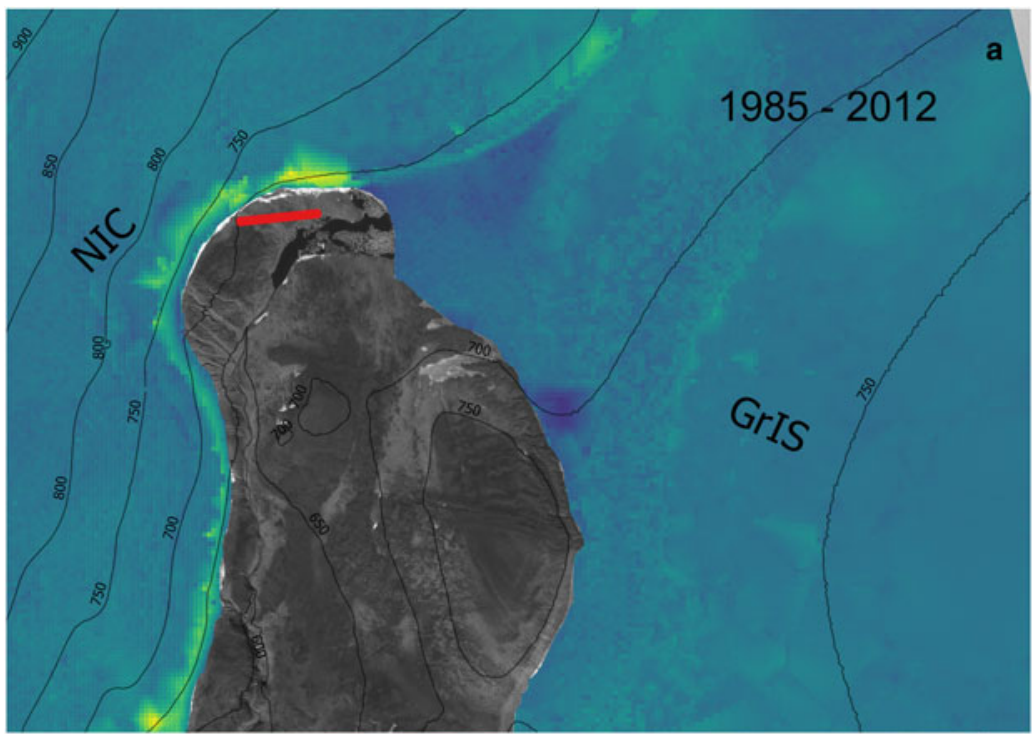

Fig. 8. Rate of surface elevation change between (a) 1985 and 2012 and (b) 2012-2017 in $\mathrm{m} \mathrm{a}^{-1}$. Note both panels relate to the same colour bar, which depicts negative values in red and indicates surface elevation loss. The yellow rim around the cliff margin coincides with the area that has low reliability values in Korsgaard and others (2016). The same colour code is applied for both time periods. The survey line is marked in red (cf. Fig. 3c).

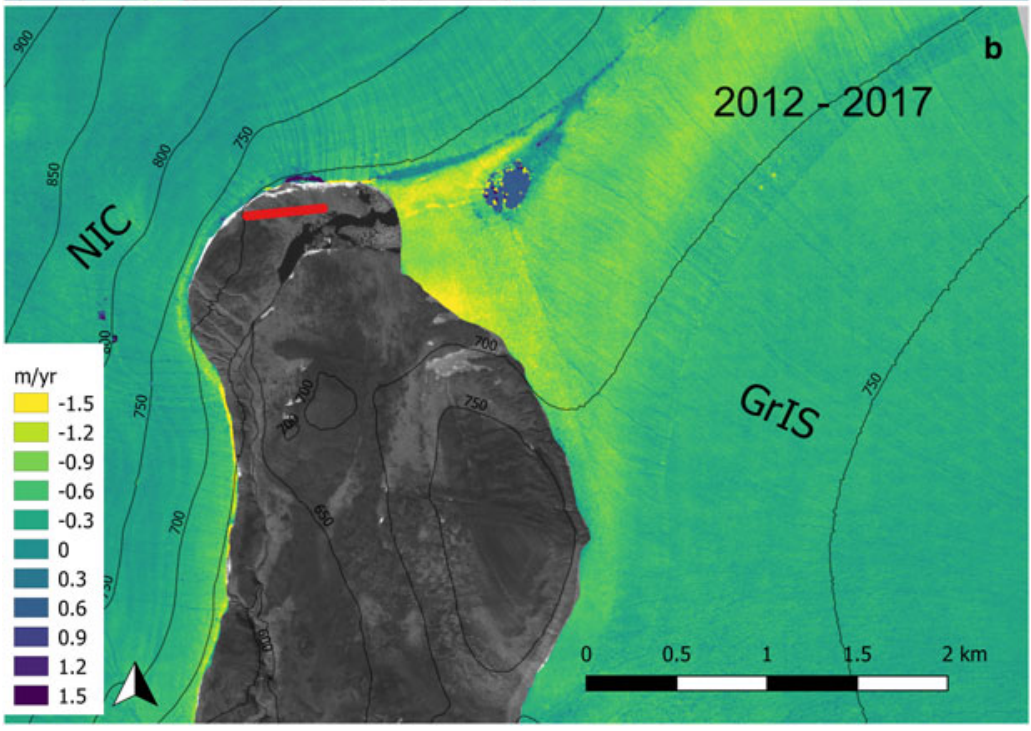

earlier been deemed plausible as an advected source by Reeh and others (2002).

\section{Conclusions}

In times of strong glacier area and volume decrease around the world, we found unique archival evidence combined with recent remote sensing and field data showing very moderate changes at the margin of a local ice cap in Northwest Greenland. After decades of minor advance with decadal mean advance rates of up to $0.7 \mathrm{~m} \mathrm{a}^{-1}$ until 1985, a phase of margin retreat followed until 2012 that then turned into an advance again. Thinning occurred throughout the entire period at different rates $(-1.5$ to $-0.1 \mathrm{~m} \mathrm{a}^{-1}$ ) with significant accelerated thinning since 2012. A qualitative comparison to air temperature and precipitation anomalies gives independent indication on drivers for the observed changes: while negative air temperature anomalies coincide with moderate thinning rates, the reverse is seen in recent years. Differences between local conditions at the NIC and the GrIS indicate stronger downwasting at the GrIS and a dynamic component balancing parts of the climatic ice surface lowering assuming otherwise similar meteorological conditions. Our study indicates several possibilities for future research: accurate positioning which was achieved in this study would allow for a re-assessment of archival ice temperature data and a comparison with modern data, which is planned to be collected in future campaigns. This could shed light on unique multi-decadal changes in strain rates and ice deformation and can, furthermore, be used to better understand the palaeo-perspective of the measured geometric and morphometric changes. Through that, improved understanding of land-terminating ice margins that respond slowly to climate change could be achieved.

Acknowledgements. The authors acknowledge the Government of Greenland for support of the reconnaissance expedition in 2017 through the Tipps og Lottomidler Pulje C. Additionally, W. Colgan from GEUS is acknowledged for providing GPR equipment and Asiaq, Greenland Survey, for logistical support. JFS would like to acknowledge support from the European Research Council (ERC) under the European Union's Horizon 2020 research and innovation program (grant number 676819). The Pléiades stereo-pair used in this study was provided by the Pléiades Glacier Observatory initiative of the French Space Agency (CNES). Graz University is acknowledged for support of publication costs. The authors thank A. Bjørk, one anonymous reviewer and H. Jiskoot for constructive feedback on the paper.

\section{References}

Bales RC and 9 others (2009) Annual accumulation for Greenland updated using ice core data developed during 2000-2006 and analysis of daily coastal meteorological data. Journal of Geophysical Research 114(D6), D06116. doi: 10.1029/2008JD011208 
Berthier E and 10 others (2014) Glacier topography and elevation changes derived from Pléiades sub-meter stereo images. The Cryosphere 8(6), 2275-2291. doi: 10.5194/tc-8-2275-2014

Bjørk AA, Kruse LM and Michaelsen PB (2015) Brief communication: getting Greenland's glaciers right - a new data set of all official Greenlandic glacier names. The Cryosphere 9(6), 2215-2218. doi: 10.5194/tc-9-2215-2015

Bolch T and 6 others (2013) Mass loss of Greenland's glaciers and ice caps 2003-2008 revealed from ICESat laser altimetry data. Geophysical Research Letters 40(5), 875-881. doi: 10.1002/grl.50270

Box JE and 6 others (2018) Global sea-level contribution from Arctic land ice: 1971-2017. Environmental Research Letters 13(12). doi: 10.1088/ 1748-9326/aaf2ed

Cappelen J, Vinther BM, Kern-hansen C, Vaarby E and Viskum P (2018) Greenland - DMI Historical Climate Data Collection 1784-2017, TR 18-04. Copenhagen, Denmark.

Carrivick JL, Yde JC, Knudsen NT and Kronborg C (2018) Ice-dammed lake and ice-margin evolution during the Holocene in the Kangerlussuaq area of west Greenland. Arctic Antarctic and Alpine Research 50(1). doi: 10.1080/ 15230430.2017.1420854

Chinn TJH (1989) Single folds at the margins of dry-based glaciers as indicators of a glacial advance. Annals of Glaciology 12, 23-30.

Citterio M and Ahlstrøm AP (2013) Brief communication the aerophotogrammetric map of Greenland ice masses. The Cryosphere 7(2), 445-449. doi: $10.5194 /$ tc- $7-445-2013$

Colgan W and 5 others (2016) The abandoned ice sheet base at Camp Century, Greenland, in a warming climate. Geophysical Research Letters 43, 8091-8096. doi: 10.1002/2016GL069688

Davies WE and Krinsley DB (1962) The recent regimen of the ice cap margin in North Greenland. Proceedings of the International Association of Hydrological Sciences 58, 119-130.

Davison BJ, Sole AJ, Livingstone SJ, Cowton TR and Nienow PW (2019) The influence of hydrology on the dynamics of land-terminating sectors of the Greenland ice sheet. Frontiers in Earth Science 7, 10. doi: 10.3389/ feart.2019.00010

Dawes PR and van As D (2010) An advancing glacier in a recessive ice regime: Berlingske Bræ, North-West Greenland. Geological Survey of Denmark and Greenland Bulletin 20, 79-82.

Evans D (1989) Apron entrainment at the margins of sub-polar glaciers, North-West Ellesmere Island, Canadian High Arctic. Journal of Glaciology 35, 317-324.

Farnsworth LB and 7 others (2018) Holocene history of the Greenland icesheet margin in Northern Nunatarssuaq, Northwest Greenland. Arktos 4 (1), 10. doi: 10.1007/s41063-018-0044-0

Felikson D and 11 others (2017) Inland thinning on the Greenland ice sheet controlled by outlet glacier geometry. Nature Geoscience 10(5), 366-369. doi: $10.1038 /$ ngeo2934

Fitzsimons S and 5 others (2008) Mechanisms of basal ice formation in polar glaciers: an evaluation of the apron entrainment model. Journal of Geophysical Research 113(F2), F02010. doi: 10.1029/2006JF000698

Fitzsimons SJ and Colhoun EA (1995) Form, structure and stability of the margin of the Antarctic ice sheet, Vestfold Hills and Bunger Hills, East Antarctica. Antarctic Science 7(2), 171-179. doi: 10.1017/S095410209500023X

Fountain AG, Neumann TA, Glenn PL and Chinn T (2004a) Can climate warming induce glacier advance in Taylor Valley, Antarctica? Journal of Glaciology 50(171), 556-564.

Fountain AG, Neumann TA, Glenn PL and Chinn T (2004b) Can warming induce advances of polar glaciers, Taylor Valley, Antarctica. Journal of Glaciology 50(171), 556-564.

Fristrup B (1963) Inlandsisen. Copenhagen: Rhodos.

Goldthwait RP (1956) Study of Ice Cliff Nunatarssuaq, Greenland. SIPRE Annual Report 11. Columbus (Ohio).

Goldthwait RP (1960) Study of Ice Cliff in Nunatarssuaq, Greenland. CRREL Technical Report 39. Hanover (New Hampshire).

Goldthwait RP (1961) Regimen of an ice cliff on land in Northwest Greenland. Folia Geografica Danica 9, 107-115.

Goldthwait RP (1971) Restudy of Red Rock Ice Cliff Nunatarssuaq, Greenland. CRREL Technical Report 224. Hanover (New Hampshire).

Herron S and Langway CC (1979) The debris-laden ice at the bottom of the Greenland ice sheet. Journal of Glaciology 23(89), 193-207. doi: 10.1017/ S002214300002983X

Hilty R (1956) Glaciological Study of an Ice Cliff in Northwest Greenland (MS Thesis). Ohio State University.
Hooke RL (1970) Morphology of the ice-sheet margin near Thule, Greenland. Journal of Glaciology 9(57), 303-324. doi: 10.3189/ S0022143000022851

Howat IM and Eddy A (2011) Multi-decadal retreat of Greenland's marineterminating glaciers. Journal of Glaciology 57(203), 389-396. doi: 10.3189/ 002214311796905631

Huss $\mathbf{M}$ and Hock R (2015) A new model for global glacier change and sea-level rise. Frontiers in Earth Science 3, 1-22. doi: 10.3389/feart.2015. 00054

Jacob T, Wahr J, Pfeffer WT and Swenson S (2012) Recent contributions of glaciers and ice caps to sea level rise. Nature 482(7386), 514-518. doi: 10. 1038/nature 10847

Jury HL (1957) An application of terrestrial photogrammetry to glaciology in Greenland. Photogrammetric Engineering and Remote Sensing 23, 543-550.

Kjeldsen KK and 14 others (2015) Spatial and temporal distribution of mass loss from the Greenland ice sheet since AD 1900. Nature 528, 396-400. doi: $10.1038 /$ nature 16183

Knutz PC and 6 others (2019) Eleven phases of Greenland ice sheet shelf-edge advance over the past 2.7 million years. Nature Geoscience 12, 361-368. doi: 10.1038/s41561-019-0340-8.

Korsgaard NJ and 6 others (2016) Data descriptor: digital elevation model and orthophotographs of Greenland based on aerial photographs from 1978-1987. Scientific Data 3, 1-15. doi: 10.1038/sdata.2016.32

Koziol CP and Arnold N (2018) Modelling seasonal meltwater forcing of the velocity of land-terminating margins of the Greenland ice sheet. The Cryosphere 12(3), 971-991. doi: 10.5194/tc-12-971-2018

Landauer J (1958) Some preliminary observations on the plasticity of Greenland Glaciers. Journal of Glaciology 3(26), 468-474.

Larsen NK and 7 others (2018) Instability of the Northeast Greenland ice stream over the last 45,000 years. Nature Communications 9(1), 3-10. doi: 10.1038/s41467-018-04312-7

Leclercq PW and 5 others (2012) Brief communication: Historical glacier length changes in West Greenland. The Cryosphere 6, 1339-1343. doi: 10. 5194/tc-6-1339-2012

Lesnek AJ and Briner JP (2018) Response of a land-terminating sector of the western Greenland ice sheet to early Holocene climate change: evidence from $10 \mathrm{Be}$ dating in the Søndre Isortoq region. Quaternary Science Review 180, 145-156. doi: 10.1016/j.quascirev.2017.11.028

Machguth $\mathbf{H}$ and 8 others (2013) The future sea-level rise contribution of Greenland's glaciers and ice caps. Environonmental Research Letters 8(2), 025005. doi: 10.1088/1748-9326/8/2/025005

Meredith M and 13 others (2019) Polar regions. In Pörtner H.-O and 12 others eds. IPCC Special Report on the Ocean and Cryosphere in a Changing Climate. In press.

Nagler T, Rott H, Hetzenecker M, Wuite J and Potin P (2015) The Sentinel-1 mission: new opportunities for ice sheet observations. Remote Sensing 7, 9371-9389. doi: doi:10.3390/rs70709371

Nielsen H and Nielsen KH (2016) Camp century - cold war city under the ice. In Doel RE Harper KE and Heymann M eds. Exploring Greenland: Cold War Science and Technology on Ice. New York: Palgrave Macmillan, pp. 195-216.

Nobles LH (1960) Glaciological investigations, Nunatarssuaq ice ramp, Northwestern Greenland. CRREL Technical Report 66.

Nobles LH (1964) Investigations of structure and movement on the steep ice ramp near Red Rock Lake Nunatarssuaq, Greenland. CRREL Technical Report 43.

Nuth C and Kääb A (2011) Co-registration and bias corrections of satellite elevation data sets for quantifying glacier thickness change. The Cryosphere 5, 271-290. doi: 10.5194/tc-5-271-2011

Osterberg EC and 5 others (2015) Coastal ice-core record of recent northwest Greenland temperature and sea-ice concentration. Journal of Glaciology $\mathbf{6 1}$ (230), 1137-1146. doi: 10.3189/2015JoG15J054

Prinz R, Heller A, Ladner M, Nicholson LI and Kaser G (2018) Mapping the loss of Mt. Kenya's glaciers: an example of the challenges of satellite monitoring of very small glaciers. Geosciences 8(5), 1-14. doi: 10.3390/ geosciences 8050174

Pritchard HD, Arthern RJ, Vaughan DG and Edwards L (2009) Extensive dynamic thinning on the margins of the Greenland and Antarctic ice sheets. Nature 461(7266), 971-975. doi: 10.1038/nature08471

Rastner P and 5 others (2012) The first complete inventory of the local glaciers and ice caps on Greenland. The Cryosphere 6(6), 1483-1495. doi: $10.5194 /$ tc-6-1483-2012 
Reeh N, Oerter H, Letréguilly A, Miller H and Hubberten HW (1991) A new, detailed ice-age oxygen-18 record from the ice-sheet margin in central West Greenland. Global and Planetary Change 4(4), 373-383. doi: 10.1016/ 0921-8181(91)90003-F

Reeh N, Oerter H and Thomsen HH (2002) Comparison between Greenland ice-margin and ice-core oxygen-18 records. Annals of Glaciology 35, 136144. doi: $10.3189 / 172756402781817365$

Shean DE and 6 others (2016) An automated, open-source pipeline for mass production of digital elevation models (DEMs) from very-highresolution commercial stereo satellite imagery. ISPRS Journal of Photogrammetry and Remote Sensing 116, 101-117. doi: 10.1016/j.isprsjprs. 2016.03.012

Sole A, Payne T, Bamber J, Nienow P and Krabill W (2008) Testing hypotheses of the cause of peripheral thinning of the Greenland ice sheet: is land-terminating ice thinning at anomalously high rates? The Cryosphere 2, 205-218. doi: 10.5194/tc-2-205-2008
Swanger KM, Lamp JL, Winckler G, Schaefer JM and Marchant DR (2017) Glacier advance during marine isotope stage 11 in the McMurdo dry valleys of Antarctica. Scientific Reports 7, 1-9. doi: 10.1038/srep41433

Tedstone AJ and 5 others (2015) Decadal slowdown of a land-terminating sector of the Greenland ice sheet despite warming. Nature 526(7575), 692-695. doi: 10.1038/nature15722

Weidick A (1968) Observations on some Holocene glacier fluctuations in West Greenland. Meddelelser om Grønland 165(6), 202.

White S (1958) Preliminary studies of motion of an ice cliff Nunatarssuaq, Northwest Greenland 1955. IAHS Symposium de Chamonix, 64-71.

Wong GJ and 5 others (2015) Coast-to-interior gradient in recent northwest Greenland precipitation trends (1952-2012). Environmental Research Letters 10(11), 114008. doi: 10.1088/1748-9326/10/11/114008

Zemp M and 12 others (2019) Global glacier mass changes and their contributions to sea-level rise from 1961 to 2016. Nature 568, 382-386. doi: 10 1038/s41586-019-1071-0 